\title{
Participative integrated development planning praxis in local government: The case of selected South African municipalities
}

\begin{tabular}{|c|c|}
\hline \multicolumn{2}{|c|}{$\begin{array}{l}\text { Authors: } \\
\text { David J. Fourie }{ }^{1} \text { (D) } \\
\text { Gerrit van der Waldt }{ }^{2} \text { (D) }\end{array}$} \\
\hline \multicolumn{2}{|c|}{$\begin{array}{l}\text { Affiliations: } \\
{ }^{1} \text { School of Public } \\
\text { Management and } \\
\text { Administration, Faculty of } \\
\text { Economic and Management } \\
\text { Sciences, University of } \\
\text { Pretoria, Pretoria, } \\
\text { South Africa }\end{array}$} \\
\hline \multicolumn{2}{|c|}{$\begin{array}{l}{ }^{2} \text { Focus Area: Social } \\
\text { Transformation, Faculty of } \\
\text { Humanities, North-West } \\
\text { University, Potchefstroom, } \\
\text { South Africa }\end{array}$} \\
\hline \multicolumn{2}{|c|}{$\begin{array}{l}\text { Corresponding author: } \\
\text { David Fourie, } \\
\text { prof.djfourie@up.ac.za }\end{array}$} \\
\hline \multicolumn{2}{|c|}{$\begin{array}{l}\text { Dates: } \\
\text { Received: } 17 \text { Sept. } 2021 \\
\text { Accepted: } 08 \text { Oct. } 2021 \\
\text { Published: } 30 \text { Nov. } 2021\end{array}$} \\
\hline \multicolumn{2}{|c|}{$\begin{array}{l}\text { How to cite this article: } \\
\text { Fourie, D.J. \& Van der } \\
\text { Waldt, G., 2021, 'Participative } \\
\text { integrated development } \\
\text { planning praxis in local } \\
\text { government: The case of } \\
\text { selected South African } \\
\text { municipalities', Journal of } \\
\text { Local Government Research } \\
\text { and Innovation 2(0), a43. } \\
\text { https://doi.org/10.4102/ } \\
\text { jolgri.v2i0.43 }\end{array}$} \\
\hline \multicolumn{2}{|c|}{$\begin{array}{l}\text { Copyright: } \\
\text { (C) 2021. The Authors. } \\
\text { Licensee: AOSIS. This work } \\
\text { is licensed under the Creati } \\
\text { Commons Attribution } \\
\text { License. }\end{array}$} \\
\hline \multicolumn{2}{|l|}{ Read online: } \\
\hline 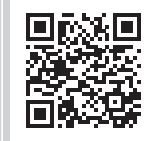 & $\begin{array}{l}\text { Scan this QR } \\
\text { code with your } \\
\text { smart phone or } \\
\text { mobile device } \\
\text { to read online. }\end{array}$ \\
\hline
\end{tabular}

Background: Municipalities have a moral and legal obligation to involve communities in determining, prioritising and realising socio-economic development needs. To achieve this aim, municipalities should use integrated development planning, which implies a sequential, phased process. Municipalities should engage the local communities in each phase. For this purpose, and based on unique demographic realities, various means of participation should be used.

Aim: The aim was to present and reflect on the results of a survey conducted in selected South African municipalities to ascertain the status of integrated development planning design and implementation in the sampled municipalities, with a particular reference to community participation praxis.

Setting: Senior managers in 11 randomly sampled local, district and metropolitan municipalities. Participants included municipal managers as chief accounting officers, chief financial officers, executive directors and functional heads of department.

Methods: A qualitative survey research design was followed utilising a desktop survey and semi-structured interviews as data collection methods. Input was obtained from senior managers $(n=52)$ in 11 randomly sampled local, district and metropolitan municipalities.

Results: The survey revealed significant disparities between high capacity urban municipalities and deep rural low-capacity municipalities regarding the effectiveness of community participation mechanisms and development planning engagement.

Conclusion: Integrated development planning is crucial to address the diverse and complex nature of development challenges experienced by most of the South African population. The IDPs of municipalities are critical instruments to guide municipalities in determining and addressing targeted needs in urban and rural communities. Recommendations are proposed to address the planning participation deficit.

Keywords: integrated development planning; South Africa; municipalities; community participation; consultation; engagement mechanisms; JEL codes: R58; R11; Z13.

\section{Introduction}

The system of governance in South Africa is characterised by three distinct, but interdependent tiers, namely the national, provincial and local government spheres. The local sphere of government consists of eight metropolitans, 44 districts and 205 local municipalities. There are significant disparities between these municipalities: they range from world-class, high-capacity metropolitan municipalities to deep rural, sometimes almost dysfunctional, local municipalities. These differences make uniform integrated urban planning praxis almost impossible. The extreme complexity of the situation on the ground makes it necessary for municipal councils to consider their unique conditions and circumstances very carefully in designing their integrated development plans (IDPs).

According to section 152 of the Constitution of the Republic of South Africa, 1996, one of the key objectives of local government is to 'promote social and economic development' (RSA 1996). The developmental role of municipalities was already indicated in the Development Facilitation Act, 67 of 1995 (RSA 1995) and is reiterated in the White Paper on Local Government, 1998 (RSA 1998b). Moreover, Chapter 5 of the Local Government: Municipal Structures Act, 117 of 1998 (RSA 1998a) stipulates the functions and powers of municipalities in fulfilling this obligation. Additional details are specified in section 23(1) of the Local Government: Municipal Systems Act, 32 of 2000, which emphasises the developmental role that municipalities should fulfil and prescribes the use of IDPs as the process through which a municipality should establish a development plan for the 
short, medium and long term (RSA 2000). This implies that all municipalities are obligated to compile and adopt a formal IDP for a given 5-year period. This plan has to be reviewed annually and, if necessary, amended. The statutory framework governing integrated development planning strongly emphasises the participatory and consultative nature of such planning and requires municipalities to engage communities as key stakeholders in determining, prioritising and realising socio-economic development needs. To maintain a healthy local democracy and foster the legitimacy of municipal councils, such needs should be included in the IDP and should be met by implementing detailed service delivery and budget implementation plans.

The purpose of this article is to reflect on the findings of an empirical survey undertaken in a sample of municipalities in South Africa to identify integrated development planning needs and challenges, with a specific reference to community participation praxis. Particular deficiencies in the process and means of gaining participation are identified and recommendations are proposed in order to address the identified weaknesses and limitations. The study began with a literature survey of the applicable legislation and IDP process, which is presented before the methodology and discussion of the results to contextualise the survey.

\section{Contextualising integrated development planning in municipalities}

Municipal planning as an official requirement in South Africa commenced in the 1930s, but it was originally conducted mainly on a fragmented, racially segregated basis (Friedman 2004:23). For decades, it was primarily aimed at accommodating the needs of privileged groups and was silent on matters such as poverty alleviation and social equity (Hofisi 2014:1127; Sebei 2013:3; Petzer, Oranje \& Van Huyssteen 2000:12). During the 1970s and 1980s, politically motivated turmoil arising from race-based inequities gave rise to the emergence of civic movements that mobilised themselves in order to make communities' collective voices heard. Political transformation in the early 1990s led to several issue-specific negotiation forums (Friedman 2004:24). Observers such as Harrison (2001) and Gueli, Van Huyssteen and Liebenberg (2007) maintain that these forums provided the main impetus for the emergence of notions of 'integrated' development planning. The shift towards a more integrated form of development planning was also strongly informed by well-established planning theory and international socioeconomic development trends and events (Sebei 2013:21). Integrated development planning typically combines various sectoral concerns and aligns multi-sphere development interests.

A formal integrated planning approach was established in South Africa after democratisation in 1994. Its main purpose was to create a national platform where national, provincial, municipal and other key stakeholders could deliberate and reach a consensus on 'apex' development priorities and could devise longer-term development strategies for the country (Maake 2016:22). It was envisaged that such development needs and priorities should emerge at the grassroots levels, meaning that communities should participate directly in planning and in determining suitable strategic development interventions (Gueli et al. 2007:6; Hlongwane 2011:37; Madumo 2015:155). The Local Government Transition Act, 209 of 1993 (RSA 1993), which was repealed 5 years later by the Local Government: Municipal Structures Act, 117 of 1998 (RSA 1998a), the Development Facilitation Act, 67 of 1995 (RSA 1995), which was eventually repealed by the Spatial Planning and Land Use Management Act, 16 of 2013 (RSA 2013) and the White Paper on Local Government, 1998 (RSA 1998b) all strongly affirm the participatory nature of development planning.

South Africa has a co-operative system of governance, implying that the respective spheres of government must align, integrate and coordinate their planning efforts. National planning is mainly the responsibility of the National Planning Commission, located in the Office of the Presidency. National planning encompasses strategies and policies for the country as a whole. In this regard, the National Development Plan: Vision 2030 (RSA 2012) currently serves as an overarching strategic framework for development planning. Provincial planning is province specific and is based on the policies and principles formulated at the national level. Each province should plan for the unique circumstances in its area of jurisdiction and annually revise its provincial growth and development plans accordingly. Municipal planning is the most detailed operational level of planning, as it addresses socio-economic development realities and concerns at a community level. The official planning document of municipalities is the IDP. Each local municipality's IDP should be aligned with those of district municipalities, which must, in turn, be aligned with the growth and development plans of provinces. The IDP should also guide the provincial and national sector departments when allocating resources to local government. The IDP thus serves as an overarching framework that links issue-based policies required by national and provincial policy, legislation and sectoral plans to the development needs of the municipal community (Ntlabezo 2013:11). Moreover, municipalities should consider the sector departments' policies and programmes in developing their own policies and strategies. It is thus in the interest of sector departments to participate in the IDP process so as to ensure that their programmes and those of municipalities are aligned (Musitha 2012:11).

\section{Municipal integrated development planning processes}

The specific requirements, contents and processes of development plans on the respective spheres of government are outlined in the Integrated Planning Framework Bill, 2018 (RSA 2018). Moreover, the Local Government: Municipal Systems Act, 32 of 2000 (RSA 2000) clearly outlines the IDP process and requirements. The IDP of municipalities should, for example, include a long-term development vision for the municipality, an assessment of existing levels of development, the identification of development priorities, the design of development strategies, a spatial development framework, disaster management plans, a financial plan, as well as key performance indicators and targets. In the compilation of the plans, ward or communitybased plans should also be accommodated to ensure that the 
wishes of the communities are taken into consideration in the formulation of the IDP (Afesis-corplan 2013:12). The IDP manager is responsible, together with the IDP representative forum, for compiling the plan.

The composition of the representative forum is prescribed by section 15 of the Local Government: Municipal Planning and Performance Regulations, No. 796, 24 August 2001 (RSA 2001). The main responsibilities of these Forums are to represent the interests of a given municipality's constituency in the IDP process. This implies that the forum should establish a platform for discussion, negotiation and decision-making involving all stakeholders. Apart from senior municipal and provincial officials, the forum should be comprised of representatives of civil society (such as ward committee councillors), communitybased organisations and representatives of organised business. The forum should represent sectoral interests, which can typically be divided into the following sectors:

- agriculture and rural development;

- economic growth;

- environmental sustainability;

- vulnerable groups and community safety;

- youth, education and higher learning and early childhood development and

- $\quad$ arts, crafts, sports and culture.

A municipality can only claim to have successfully adopted an IDP once it has conducted certain processes in an organised manner (Maake 2016:68). The process follows a logical and sequential phased approach. Hence, scholars such as Motingoe (2011), Ntlabezo (2013) and Sebei (2013) argue that these phases are highly interrelated and interdependent. This means that changes in any one of the phases may influence one or all of the other phases. Each phase requires the municipality to engage communities. Therefore, it is necessary to elucidate each phase briefly below.

\section{Phase 1: Planning}

Section 27 of the Municipal Systems Act requires every South African municipality to adopt a planning framework for integrated development. The framework should be the result of a consultative process and must include the following (cited verbatim):

- the plans and planning requirements as contained in legislation;

- the matters to be included in the IDP;

- the principles to be applied to determine the matters to be included;

- the approach to be used to include and adopt the matters;

- the procedures to be used for consultation between the district municipality and local municipalities and

- the procedure to be used to effect vital amendments to the framework (RSA 2000).

Section 28 of the Municipal Systems Act stipulates that the community must be consulted on the process plan and must be informed once the plan is officially approved (RSA 2000).

\section{Phase 2: Analysis}

The second phase focuses on identifying the current situation in the municipal area. The IDP should be informed by a detailed analysis of the development challenges experienced by the community (Motingoe 2011:24). Each municipality must know about the available existing and accessible resources in order to establish the municipality's limitations in the creation of realistic solutions to identified challenges (Ntlabezo 2013:23).

The output of this phase should be a comprehensive assessment of the existing level of development, the details of prioritised needs, an understanding of the causes of development challenges and information on available resources (Ntlabezo 2013:13). According to Maake (2016:69-75), this assessment should be informed by the following types of analyses:

- legal framework analysis (e.g. statutory and regulatory compliance);

- leadership guideline analysis (e.g. political and administrative leadership directives);

- community and stakeholder analysis (e.g. status of service available in the community, input from ward committees, non-governmental and community-based organisations);

- municipality technical development analysis (e.g. infrastructure status, level of essential services);

- institutional analysis (e.g. strengths and weaknesses that can affect performance by scrutinising the capacity of the municipality);

- economic analysis (e.g. contributions of economic sectors within the municipal area);

- socio-economic analysis (e.g. demographical realities, social equity, prevalence of poverty and unemployment, income distribution and per capita income);

- spatial analysis (e.g. spatial constraints, problems, opportunities, trends and patterns in order to determine the need for spatial restructuring, land reform and the spatial dimension of development issues);

- environmental analysis (e.g. environmental factors that may hamper or support development strategies and programmes such as geology, air quality, topography, climate, soils and land, fauna and flora, surface water, ground water, water quality and water pollution) and

- in-depth analysis (e.g. consolidate and integrate different data sets to assess the overall development status of the municipal area).

\section{Phase 3: Strategies}

The completion of the previous phase, Phase 2, provides the municipality with an understanding of the problems that affect the community and the causes of those problems. In Phase 3 then, the municipality has to develop a priority list and solutions to the challenges that have been prioritised (Musitha 2012:105). It is therefore essential to do a gap analysis, which involves evaluating the current reality against the envisaged destination. This exercise enables identification of key performance areas, objectives, key performance indicators, targets and action plans (Maake 2016:74; Motingoe 2011:24-25). 


\section{Phase 4: Projects}

In the fourth phase, the municipality needs to determine the design, content and specifications of the projects identified in the third phase. The projects that are identified must be directly related to the issues determined and prioritised in Phase 2 and the objectives identified in Phase 3 (Motingoe 2011:25). Distinct targets must be set and performance indicators must be designed to ensure that all projects can be measured and assessed. For each project, the following details are required:

- the target group (beneficiaries);

- the location of the project;

- the date of commencement;

- the date of completion;

- the persons responsible for managing the project;

- the cost of the project and

- sources of funding.

\section{Phase 5: Integration}

The fifth phase entails integration and consolidation to ensure that the municipality ascertains the outcomes of projects measured against the development vision, objectives, strategies and resources allocated (Motingoe 2011:26). This leads to consolidated and integrated programmes. Ntlabezo (2013:25) defines this phase as an 'operational strategy', which should include the following (cited verbatim):

- a 5-year financial plan and capital investment programme;

- an integrated spatial development framework;

- integrated sectoral programmes such as gender equality, economic development and poverty alleviation;

- consolidated performance management systems;

- disaster management plan;

- institutional plan and

- reference to relevant sector plans.

\section{Phase 6: Approval}

The previous phases should have resulted in the compilation of a draft IDP. Prior to the adoption of the IDP by a municipal council, it is essential that the community and other interested parties be provided with an opportunity to comment on the draft plan. This phase is meant to provide the approved plan with a sound basis of relevance, support and legitimacy (Motingoe 2011:26). The final IDP must be submitted to the municipal council for consideration and approval. The council should evaluate the plan and determine whether it accommodates the identified development challenges and whether the strategies formulated in the IDP are suitable to address these challenges (Ntlabezo 2013:25).

\section{Participatory municipal development planning}

Participatory democracy can be regarded as a form of governance in which citizens are actively involved in the decision-making processes of government (Ababio 2004:277; Fakir 2003:7). Participatory democracy in the local sphere of government requires active engagement of communities in local decision-making processes (Mogale 2005:136; Pratchett \& Wilson 1996). Freire (1972:23) points out that real participatory democracy depends on the 'bottom-up' work of citizens to build 'critical communities' that can enter political deliberations as 'conscious and empowered forces'. Community participation and broad civic engagement are essential requirements for participatory democracy in the context of developmental local governance (Van der Waldt ed. 2007, 2010). Similarly, Gaventa and Valderrama (1999:4) indicate that community participation involves 'direct ways in which citizens influence and exercise control in local governance'. In this regard, Gonzalez de Asis and AcunaAlfaro (2002:3) explain that community participation 'builds collective action between government authorities and citizens, it raises awareness on development responsibilities by civil society, and it fosters involvement in public policy design'.

The democratic and developmental system of local government in South Africa finds expression mainly through community participation. As has already been mentioned, the statutory and regulatory framework for local government strongly underscores the participatory nature of development planning. In particular, section 152(1) of the Constitution (RSA 1996) establishes representative democracy and mandates participatory democracy as two objects of local government - it states that the objectives of local government are, amongst other things, 'to provide democratic and accountable government for local communities' and 'to encourage the involvement of communities and community organisations in the matters of local government' (RSA 1996). The White Paper on Local Government, 1998 sets out the vision of developmental local government by characterising it as a:

[S]ystem which is committed to working with citizens, groups and communities to create sustainable human settlements which provide for a decent quality of life and which meet the social, economic and material needs of communities in a holistic way. (RSA 1998b, p. 23)

Musitha (2012:102) and Hlongwane (2011:13) also stress the fact that municipal councils are responsible for enhancing local democracy and promoting broad socio-economic development through active community participation.

Chapter 4 of the Local Government: Municipal Systems Act, 32 of 2000 requires municipal councils to establish and inculcate a culture of community participation. It also sets out mechanisms, processes and procedures that councils should pursue to facilitate such engagement (RSA 2000). This includes mechanisms to communicate information and give notice of public meetings. Chapter 4 of the Act also deals with admission of the public to meetings and sets regulations and guidelines for consultations. Section 21 of the Act further stipulates the manner in which communication to communities should occur. This includes the use of local newspapers, radio broadcasts, official notices, submissions and representations to councils. In respect of establishing participation mechanisms, the Act requires municipalities to take into account the special needs of the people who need to be reached, especially those who cannot read or write, people with disabilities, women and other disadvantaged or marginalised groups.

As far as community participation in the IDP process is concerned, the Local Government: Municipal Systems Act, 32 of 
2000 is supplemented with various official guidelines. One of these is the National Policy Framework for Public Participation (DPLG 2007), which outlines the principles of public participation, including inclusivity, empowerment, trust, transparency, flexibility and accessibility. Furthermore, the South African Local Government Association's (SALGA 2011) Guideline Document on the Roles and Responsibility of Councillors, Political Structures and Officials emphasises the need for a responsive, transparent and unbiased administration that fosters participation in local decision-making. Then there is the Department of Public Service and Administration's (DPSA 2014:16-17) Guide on Public Participation in the Public Service, which makes provision for the design of institutional policies on public participation, the establishment of citizen forums, participation toolkits, satisfaction citizen surveys and the training of officials involved in public participation processes.

With a particular reference to participation in the IDP process, these guideline documents pinpoint the following participation mechanisms for municipalities:

- the IDP representative forum;

- advertisements in local newspapers and radio stations;

- municipal websites;

- notices at municipal offices;

- loud-hailing;

- information sheets distributed by ward committees;

- the imbizo (public meeting);

- public hearings;

- ward committees and

- community development workers.

There is, however, limited empirical evidence regarding the suitability and effectiveness of these mechanisms in the IDP process. It seems that especially low-capacity local municipalities struggle to use these mechanisms and fulfil their obligations to promote community participation in the IDP process. Scholars such as Hlongwane (2011), Musitha (2012), Madumo (2015) and Thebe (2016) concur that the official IDPs of municipalities generally do not outline the extent to which the community is to be or has been involved throughout the IDP process. Official reports and research by Madumo (2015:154), and Maake (2016) confirm that communities generally only participate meaningfully during the first phase in the IDP cycle. They are then only consulted again after the approval of the Draft IDP by Council, mainly to inform them of the programmes and projects that will take place in the next financial year. Furthermore, municipalities, in general, focus more on mere information-sharing mechanisms such as newsletters, annual general meetings, information points or help centres and on strategic partnerships with various stakeholders in the community (IDASA 2011:5).

Some municipalities have initiated additional mechanisms for information-sharing purposes, such as the compilation of databases of all relevant community and stakeholder organisations, informing communities and stakeholders through campaigns and advertisements in local newspapers, notices in prominent locations such as pay points, direct mail, leaflets with service bills, distribution of pamphlets and posters to ward committees and radio announcements (Hlongwane 2011). These mechanisms are generally sufficient to share information but do not suffice to engage communities constructively or to obtain their responses or feedback during the relevant phases of the IDP (Maake 2016).

The result is that community consultations do not have enough of an impact on development priorities and decisions. This problem is highlighted by Everatt, Marais and Dube (2010:236), who argue that the IDP process normally extends over 8 to 10 months, but that public participation occurs only at a few discrete points during this period. This is counterproductive: Sisk and Ballington (2001:163) warn that participatory approaches will founder if people believe that they are being used to legitimise decisions that have already been taken or that the results of their efforts will not matter in the long run ... citizens and civic groups will quickly recognise when a process is a mask for a top-down decision-implementation and when the views of participants are genuinely sought.

Other researchers who advocate local participation during all phases of the IDP are Gueli et al. (2007:104) and Hofisi (2014:1132), who call for participation to be applied throughout, not exclusively for initial assessments and the prioritisation of development needs. The prior evidence on the absence of such participation warrants empirical investigation to confirm the status of community participation in municipal IDPs.

\section{Method}

Following a qualitative research design, a survey was undertaken to ascertain the status of IDPs and community participation praxis in a sample of South African municipalities. The survey followed a phased approach. The first phase entailed a conceptual, contextual and situational analysis. By means of a desktop survey, the statutory and regulatory requirements and prescripts for IDPs in municipalities were analysed (as set out above).

The second phase concerned the design of an interview schedule to obtain information pertaining to IDP challenges, with a specific reference to community participation and consultation. Input was obtained from senior managers in 11 randomly sampled local, district and metropolitan municipalities (representative of rural low-capacity and urban high-capacity municipalities). Municipalities located in different provinces were selected to gain a broader geographical and demographical perspective, specifically regarding issues related to culture and ethnicity. The sampled municipalities were the following:

- Alfred Duma Local Municipality (KwaZulu-Natal).

- Amajuba District Municipality (KwaZulu-Natal).

- Ekurhuleni Metropolitan Municipality (Gauteng).

- Emalahleni Local Municipality (Mpumalanga, local municipality which falls under the Nkangala District Municipality).

- Emfuleni Local Municipality (Gauteng, local municipality which falls under the Sedibeng District Municipality).

- Fezile Dabi District Municipality (Free State). 
- Frances Baard District Municipality (Northern Cape).

- Greater Letaba Local Municipality (Limpopo, local municipality that falls under the Mopani District Municipality).

- Newcastle Local Municipality (KwaZulu-Natal, local municipality that falls under the Amajuba District Municipality).

- Sol Plaatje Local Municipality (Northern Cape, local municipality that falls under the Frances Baard District Municipality).

- Tshwane Metropolitan Municipality (Gauteng).

The third phase entailed conducting face-to-face, semistructured interviews with the target population. Four (local) and five (district and metro) senior managers per municipality were sampled $(n=52)$. Participants included municipal managers as chief accounting officers, chief financial officers, executive directors and functional heads of department. Sampled participants signed a declaration indicating consent to participate voluntarily, and the anonymity and confidentiality of their responses was ensured. The interview schedule was pre-tested (piloted) with senior managers in one of the sampled municipalities.

The fourth and final phase involved data analysis, including the final verification and cross-referencing of findings. Content and narrative analyses were utilised for sense making purposes of the data obtained from the desktop survey and interviews.

\section{Results and discussion of findings}

The first part of the survey (Questions 1-5) was aimed at ascertaining the demographic profiles of participants. The majority $(67 \%)$ occupied positions as municipal managers, functional heads and deputy directors. Most participants $(75 \%)$ had more than 10 years of local government experience and $88 \%$ of them held tertiary qualifications. The findings confirmed that the profile of the sampled target population was fully conducive to their providing relevant, accurate and informed responses.

The second part of the survey was aimed at ascertaining the status of IDP processes in the municipality and exploring the challenges and praxis pertaining to community participation in the IDP process. Various dimensions of the IDP process were accommodated in the interview schedule. The data were obtained from eight open-ended and five Likert-style questions. Some questions were divided into sub-questions to facilitate the collection of rich data.

Question 6 asked 'How would you rate the overall legitimacy of the municipal council in the community?' The question was posed to determine the opinions of senior managers regarding the current level of engagement with the community and how healthy they perceive the interaction in the IDP participation process between the municipality and the community. The combined rating of $81 \%$ for 'Adequate', 'Good' and 'Excellent' seems positive. However, this response should be compared to and read in the light of the limitations and challenges identified as currently hampering the IDP process, as identified in Questions 11, 12 and 13, where participants singled out the lack of participation and limited stakeholder engagement as the most significant challenge.

To ascertain the status of the analysis phase of the IDP process, Question 7 asked: 'Do you conduct regular community profiling endeavours to understand the demographical realities, and infrastructure and service delivery challenges?' The relatively low affirmative response of $65 \%(n=34 / 52)$ is concerning, implying that this foundational phase of the IDP is not adequately managed and does not comply with the respective types of analysis to be undertaken. It should be noted that the success of the IDP process hinges on strong evidence regarding the development needs and priorities of the municipal area.

Question 8a was designed to identify the mechanisms that municipalities use to determine development needs in the community, whereas Question $8 \mathrm{~b}$ requested participants to indicate the frequency of the determination of such needs. The findings are reflected in Tables 1 and 2.

Most participants indicated that their municipalities use the IDP review process as the primary mechanism to identify development needs. This finding supports the contention

TABLE 1: Question 8a: Mechanisms for the identification of development needs.

\begin{tabular}{lcc}
\hline Results & Number of participants $(\boldsymbol{n}=\mathbf{5 2})$ & $\mathbf{\%}$ \\
\hline Through IDP review processes & 21 & 40 \\
Public meetings & 11 & 21 \\
Public representations & 6 & 12 \\
Road shows & 5 & 10 \\
Imbizo & 4 & 8 \\
Councillors engaging community & 3 & 6 \\
Community surveys & 2 & 4 \\
Ward committees & 2 & 4 \\
House visits & 2 & 4 \\
Questionnaires & 2 & 4 \\
Public consultations & 1 & 2 \\
Meeting clients, visiting services & 1 & 2 \\
Updating community profile & 1 & 2 \\
Reports from various departments & 1 & 2 \\
Community outreach initiatives & 1 & 2 \\
Stakeholder engagement initiatives & 1 & 2 \\
Call centres & 1 & 2 \\
*Unsure/no response & 4 & 8 \\
\hline
\end{tabular}

IDP, integrated development plans

TABLE 2: Question 8b: Frequency of the identification of development needs.

\begin{tabular}{lcc}
\hline Results (frequency) & Number of participants $(\boldsymbol{n}=\mathbf{5 2})$ & $\mathbf{\%}$ \\
\hline Every 3 years & 1 & 2 \\
Annually & 33 & 63 \\
Six monthly & 4 & 8 \\
Quarterly & 15 & 29 \\
Monthly & 5 & 10 \\
Twice a month & 1 & 2 \\
Ad hoc & 3 & 6 \\
$*$ Unsure/no response & 5 & 10 \\
\hline
\end{tabular}


that municipalities generally comply with their legal obligations in this regard. The mechanisms that are mainly employed to engage with local communities include public meetings $(21 \%)$, public representations in open council meetings $(12 \%)$, roadshows $(10 \%)$ and the imbizo $(8 \%)$. It should be noted, however, that the success of the entire IDP hinges on the quality of data and statistics regarding development needs. The various analyses that should be undertaken during Phase 2 of the IDP process should add a significant value in this regard. The other mechanisms identified should merely support these analyses and cannot be used in isolation (instead of analyses), because people will usually only communicate needs in their personal capacity or what they experience in their own wards. It is imperative that a more holistic perspective of the entire municipal area be obtained. The fact that only $40 \%$ of participants indicated that the IDP review process is the main mechanism for data collection regarding the development needs of the community is thus a matter for concern.

Regarding the frequency of the identification of development needs, $63 \%$ of the participants indicated that the municipality does so annually; $29 \%$ claimed that their municipality undertakes this exercise on a quarterly basis. These responses make sense given the annual review cycle of the IDP, as well as the compilation of quarterly performance reports that the respective municipal departments must submit to the municipal council.

A further worrying issue is the fact that a relatively high percentage of participants were unsure about the manner in which the municipality identifies development needs (8\%) and how often they conduct a process to identify such needs $(10 \%)$. Based on the seniority of participants, one would logically expect that they would be actively involved in the IDP process and that the data on any development needs identified would be disseminated to, and remedies would be coordinated between municipal departments. However, this does not seem to be the case in all municipalities. It can be deduced that some administrations act and function in silos.

Question 9 and its sub-questions were formulated in line with section 29 of the Local Government: Municipal Systems Act, 32 of 2000 (RSA 2000). Participants were asked to rate the extent to which their municipality currently complied with the various requirements (see Tables 3-5 for the responses).

The combined positive responses (88\%, 'Adequate', 'Good' and 'Excellent') regarding level of community participation

TABLE 3: Question 9a: Level of community participation in development needs and priorities.

\begin{tabular}{lccc}
\hline Results & Value & Number of participants $(\boldsymbol{n}=\mathbf{5 2})$ & $\mathbf{\%}$ \\
\hline Very poor & 1 & 1 & 2 \\
Poor & 2 & 5 & 10 \\
Adequate & 3 & 18 & 34 \\
Good & 4 & 17 & 33 \\
Excellent & 5 & 11 & 21 \\
\hline
\end{tabular}

in identifying development needs and priorities (Question 9a) are encouraging. However, these results reflect only the opinions of municipal officials and not those of community members. Generalisations in this regard should thus be avoided. Furthermore, this result should be contrasted with responses to Questions 11-13, which reveal that responses to Question 9 do not correspond neatly to the limitations and challenges identified (see Figure 2 and Table 6). The lack of participation or limited participation of community and other stakeholders was identified as the most significant challenge by 11 participants (21\%).

Regarding the level of community participation in the drafting of the IDP (Question 9b, Table 4), the combined positive response of $79 \%$ confirms that municipal officials perceive themselves to comply adequately with their legal obligations to foster community participation. The level or extent to which they comply should, however, be explored further.

Table 5 shows that $82 \%$ held positive perceptions of the extent to which organs of state, including traditional authorities and other role players, are consulted in the drafting of the IDP. Again, the quality of this consultation should be confirmed by comparing and contrasting this finding with the opinions of these stakeholders.

Question 10 considered the perceived effectiveness of the community participation mechanisms in the IDP process, using a five-point Likert scale. The 'Good' and 'Excellent' responses on the scale combined reflect an overall positive rating of a particular mechanism. Figure 1 reflects the perceived comparative effectiveness of these mechanisms.

Responses show that open council meetings and local newspapers are perceived as the most effective means to engage the community in the IDP process. It would be interesting to juxtapose these findings with follow-up research in communities to ascertain whether community members agree regarding the most effective mechanisms to

TABLE 4: Question 9b: Level of community participation in the drafting of the integrated development plans.

\begin{tabular}{lccc}
\hline Results & Value & Number of participants $(\boldsymbol{n}=\mathbf{5 2})$ & $\mathbf{\%}$ \\
\hline Very poor & 1 & 2 & 4 \\
Poor & 2 & 8 & 15 \\
Adequate & 3 & 12 & 23 \\
Good & 4 & 17 & 33 \\
Excellent & 5 & 12 & 23 \\
*No response & 6 & 1 & 2 \\
\hline
\end{tabular}

TABLE 5: Question 9c: Extent to which organs of state, including traditional authorities and other role players, are consulted in the drafting of the integrated development plans.

\begin{tabular}{lccc}
\hline Results & Value & Number of participants $(\boldsymbol{n}=\mathbf{5 2})$ & $\mathbf{\%}$ \\
\hline Very poor & 1 & 3 & 6 \\
Poor & 2 & 5 & 10 \\
Adequate & 3 & 15 & 29 \\
Good & 4 & 20 & 38 \\
Excellent & 5 & 8 & 15 \\
*No response & 6 & 1 & 2 \\
\hline
\end{tabular}


become involved in municipal decision-making in general and the IDP process in particular. Variables such as age, access to information, literacy levels and socio-economic conditions of various segments of municipal communities may have a significant influence on their preferred means of participation. It is thus essential that the choice of effective mechanisms for community participation be informed by the analysis phase (Phase 2) of the IDP process.

Question 11 enquired into the overall status of the IDP process by focusing on the availability of planning support systems and mechanisms. Participants rated the availability of or access to various types of support and reflected on how much the perceived absence of these support systems and mechanisms negatively influences the quality of the IDP. Figure 2 reports the results. Again, the negative responses on the Likert scale were combined. Responses to these questions provide a more detailed insight into the perceived effectiveness of IDP planning support systems and mechanisms.

Inadequate planning alignment between local and district municipalities and between municipalities and provincial and national government was identified as the most significant IDP support challenge. Thus, more needs to be done to coordinate development planning efforts and forums

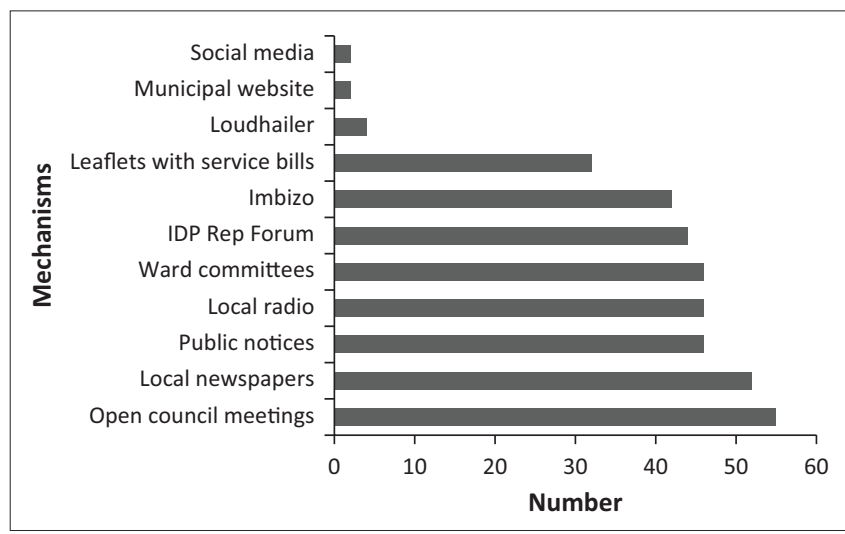

FIGURE 1: Perceived effectiveness of integrated development plans participation mechanisms.

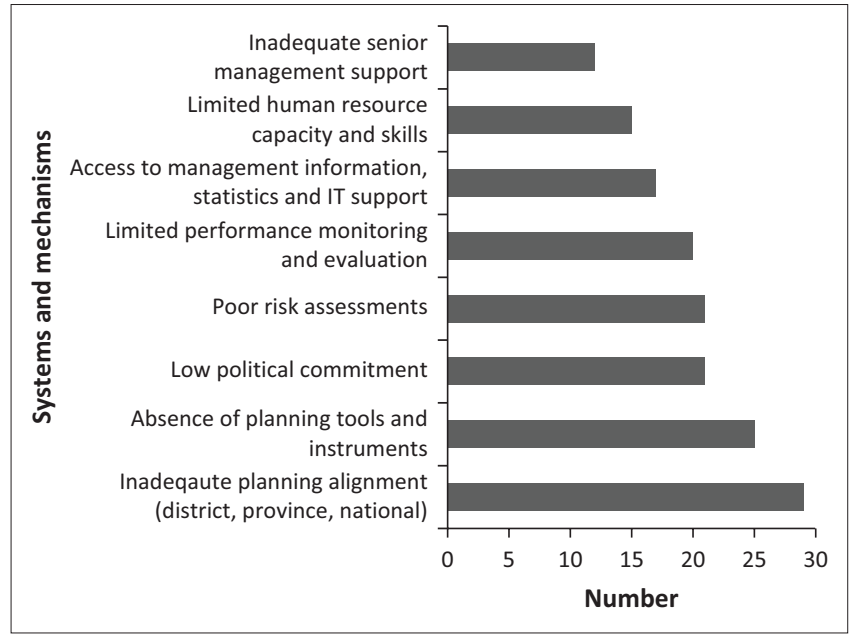

FIGURE 2: Absence of planning support systems and mechanisms detrimental to the integrated development plans process. aimed at fostering cooperative governance. Intergovernmental relations should be used to support individual municipalities with the design of their IDPs.

The responses to this question were cross-referenced with two final follow-up questions (Questions 12 and 13), where participants were requested to list the main challenges and limitations to IDP planning and say what they thought should be done to improve planning praxis for IDP purposes in their respective municipalities. Their responses are reflected in Tables 6 and 7.

The results confirmed the responses obtained in the previous question. Again, some challenges are municipality specific. Not all municipalities experienced the same challenges. A targeted approach aimed at addressing specific challenges experienced by particular municipalities is thus advised.

\section{Recommendations}

Based on the findings of the survey, two sets of recommendations can be made. The first set pertains to improving IDP praxis in municipalities in general, and the second set focuses on cultivating community participation in the IDP process.

Three general recommendations to improve municipal IDPs are made:

1. It is evident that there are significant disparities between different municipalities. The IDP improvement

TABLE 6: Main integrated development plans challenges and limitations.

\begin{tabular}{|c|c|c|}
\hline Responses & Number of participants $(n=52)$ & $\%$ \\
\hline $\begin{array}{l}\text { Lack of and limited participation of } \\
\text { community and other stakeholders }\end{array}$ & 11 & 21 \\
\hline Financial constraints & 5 & 10 \\
\hline $\begin{array}{l}\text { Lack of long-term planning aligned with } \\
\text { financial plan/budget }\end{array}$ & 5 & 10 \\
\hline Lack of consultation with stakeholders & 4 & 8 \\
\hline Lack of skills/capacity regarding IDP planning & 4 & 8 \\
\hline $\begin{array}{l}\text { Lack of or limited national and provincial } \\
\text { participation }\end{array}$ & 3 & 6 \\
\hline Lack of commitment and engagement & 2 & 4 \\
\hline Poor communication & 2 & 4 \\
\hline $\begin{array}{l}\text { High expectations of community versus } \\
\text { capability of municipality to deliver planning } \\
\text { of district municipalities }\end{array}$ & 2 & 4 \\
\hline Limited monitoring and evaluation & 1 & 2 \\
\hline Lack of implementation capacity & 1 & 2 \\
\hline Differences of opinion between political parties & 1 & 2 \\
\hline $\begin{array}{l}\text { Lack of assessment/review of provision } \\
\text { targets versus outcomes }\end{array}$ & 1 & 2 \\
\hline Lack of performance feedback & 1 & 2 \\
\hline $\begin{array}{l}\text { Unavailability of land; settlement patterns } \\
\text { in rural areas are not conducive to proper } \\
\text { planning }\end{array}$ & 1 & 2 \\
\hline Influx of foreigners & 1 & 2 \\
\hline $\begin{array}{l}\text { Municipal officials of all levels do not attend } \\
\text { meetings with the public }\end{array}$ & 1 & 2 \\
\hline Political interference & 1 & 2 \\
\hline High vacancy rate in the municipality & 1 & 2 \\
\hline Unreliable information and statistics provided & 1 & 2 \\
\hline $\begin{array}{l}\text { Silo mentality; protecting own turf and } \\
\text { resources }\end{array}$ & 1 & 2 \\
\hline
\end{tabular}

IDP, integrated development plans. 
TABLE 7: Recommendations to improve integrated development plans praxis.

\begin{tabular}{|c|c|c|}
\hline Responses & Number of participants $(n=52)$ & $\%$ \\
\hline $\begin{array}{l}\text { Improve stakeholder participation and } \\
\text { engagement }\end{array}$ & 19 & 37 \\
\hline Allocate more funding and resources & 8 & 15 \\
\hline Improve communication & 7 & 13 \\
\hline $\begin{array}{l}\text { Appoint officials capable of implementing IDP } \\
\text { resolutions }\end{array}$ & 3 & 6 \\
\hline Design a long-term plan to guide the IDP process & 3 & 6 \\
\hline Appoint more people; fill vacancies in the IDP & 3 & 6 \\
\hline $\begin{array}{l}\text { Coordinate actions of national, provincial and } \\
\text { local government }\end{array}$ & 3 & 6 \\
\hline $\begin{array}{l}\text { Proper integrated forward planning, incl. } \\
\text { financial planning }\end{array}$ & 3 & 6 \\
\hline $\begin{array}{l}\text { Increased participation by local municipalities } \\
\text { in district municipal planning }\end{array}$ & 3 & 6 \\
\hline Stabilise political leadership & 2 & 4 \\
\hline $\begin{array}{l}\text { Increase the involvement of municipal officials } \\
\text { in the community }\end{array}$ & 2 & 4 \\
\hline Skills development must be prioritised & 2 & 4 \\
\hline $\begin{array}{l}\text { Appoint specialist to assist with IDP and sector } \\
\text { planning }\end{array}$ & 2 & 4 \\
\hline $\begin{array}{l}\text { Improve participation by national and } \\
\text { provincial government }\end{array}$ & 2 & 4 \\
\hline Avoid malicious competition & 1 & 2 \\
\hline $\begin{array}{l}\text { Councillors must improve relations with the } \\
\text { community }\end{array}$ & 1 & 2 \\
\hline Limit political interference & 1 & 2 \\
\hline Empower staff to do proper scientific research & 1 & 2 \\
\hline Encourage participation by traditional leaders & 1 & 2 \\
\hline Use web-based, online platforms & 1 & 2 \\
\hline $\begin{array}{l}\text { Assign an executive director to be responsible } \\
\text { for planning }\end{array}$ & 1 & 2 \\
\hline Improve community profiling & 1 & 2 \\
\hline
\end{tabular}

IDP, integrated development plans.

interventions should thus follow a targeted approach aimed at specific practices in certain municipalities. A pragmatic approach should be adopted to suit the specific circumstances and demographic profile of some municipalities. Aspects that should receive particular attention include municipal capacity building through the appointment and upskilling of competent and experienced managers responsible for IDP planning and the filling of critical vacancies.

2. It is strongly recommended that municipalities be assisted to use more sophisticated planning tools and technical instruments aimed at securing more accurate and relevant data and statistics during the analysis phase of the IDP. Unreliable management planning information, outdated statistics and incomplete data seriously jeopardise the development planning capacity of municipalities, especially community profiling demands. Management information systems and general information technology support are essential to obtain and disseminate information to key stakeholders across all spheres of government. Existing data bases from Statistics SA, SA Cities Network, National Treasury and various consultancy groups should be aligned by using online web-based platforms.

3. Mechanisms for effecting greater synergy between development planning processes undertaken by the different spheres of government should be established. Greater alignment in respect of integrated development planning between the provincial and local spheres of government requires improved coordination and cooperation. Provincial sector departments, district municipalities and other stakeholders should participate meaningfully in the formulation and implementation of the IDPs of local municipalities.

Five recommendations are made regarding the cultivation of community participation in the IDP process:

1. It is essential that municipal councils establish and cultivate a participation ethos and culture premised on recognised democratic principles, such as openness, transparency and responsiveness. Such a culture should strengthen local democracy and contribute to the overall legitimacy of municipal councils by promoting service delivery excellence. The capacity of councillors as political representatives in their community engagement and consultation roles and responsibilities must be strengthened.

2. Discrepant responses from participants in the same municipalities suggest that municipal administrations often function in silos. The IDPrequires a multidisciplinary, multi-faceted and integrated approach. Coordination, cooperation and alignment between municipal departments are thus vital to prevent 'turf-protection' and to promote acting as equal partners in designing and executing development strategies, programmes and projects.

3. It is recommended that the performance management systems of municipalities be extended to more effectively serve as monitoring and evaluation instruments for community participation during the IDP process. Performance indicators and targets should be designed to measure the scope, level and quality of engagement in each phase of the process, and participation mechanisms should be adapted accordingly.

4. Community participation and consultation should follow a differentiated approach. The community is not a homogenous entity but consists of local businesses, the agricultural community, taxpayers' and taxi associations, religious groupings, the elderly, marginalised groups and so forth. Councils should use different participation mechanisms for each community segment, depending on demographic profiles and access to information. Hence, the design of an IDP community participation toolkit with appropriate and suitable participation mechanisms and how and when to apply them is strongly advised. Such a toolkit should take cognisance of the different participation capacities of metropolitan, district and local municipalities, as well as urban and rural realities.

5. A more holistic perspective regarding the status of community participation in the IDP process is needed. Additional research should thus compare and contrast the opinions of senior municipal officials on the scope, level and quality of participation and stakeholder engagement with those of different groupings in the community. 


\section{Conclusion}

Integrated development planning is crucial to address the diverse and complex nature of development challenges experienced by most of the South African population. The IDPs of municipalities are critical instruments to guide municipalities in determining and addressing targeted needs in urban and rural communities. Municipalities as developmental agencies are obligated to foster community participation in the entire IDP process. It is evident that this obligation is not always sufficiently adhered to. Disparities between municipalities and the demographic realities of communities call for the use of different participation mechanisms in the IDP process. The unique demographics of urban and rural communities should be accommodated in the design of community participation toolkits for metropolitan, district and local municipalities. In this way, participative integrated development planning praxis in local government can be significantly enhanced.

The implications of the study are twofold. Firstly, it is evident that a more nuanced and differentiated approach should be followed in the design and implementation of municipal IDPs. The IDPs should be fully congruent with the particular institutional capacity and community realities of municipalities. Secondly, it is apparent that more should be done to cultivate community participation in the IDP process. More research pertaining to the interfaces between planning and community participation is required to explore the suitability of certain participation mechanisms in different rural and urban planning settings.

\section{Acknowledgements Competing interests}

The authors have declared that no competing interest exists.

\section{Authors' contributions}

All authors contributed equally to this work.

\section{Ethical considerations}

The research was approved by the Research Ethics Committee: Faculty of Economic and Management Sciences, University of Pretoria and an Ethical Clearance certificate was issued. EMS 014/20.

\section{Funding information}

This research received no specific grant from any funding agency in the public, commercial or not-for-profit sectors.

\section{Data availability}

Data sharing is not applicable to this article as no new data were created or analysed in this study.

\section{Disclaimer}

The views and opinions expressed in this article are those of the authors and do not necessarily reflect the official policy or position of any affiliated agency of the authors.

\section{References}

Ababio, E.P., 2004, 'Enhancing community participation in developmental local government for improved service delivery', Journal for Public Administration 39(2), 272-289.

Afesis-corplan, 2013, Land and settlement development research study. Report on municipal planning, Umhlaba Consulting Group, viewed 10 April 2021, from http://afesis.org.za/wp-content/uploads/2017/05/Municipal_planning_final.pdf.

DPLG (Department of Provincial and Local Government), 2007, National policy framework for public participation, DPLG, Pretoria.

DPSA (Department of Public Service and Administration), 2014, Guide on public participation in the public service, DPSA, Pretoria, viewed 07 February 2021, from http://www.dpsa.gov.za/dpsa2g/documents/cdw/2014/citizenengagement.pdf.

Everatt, D., Marais, H. \& Dube, N., 2010. 'Participation ... for what purpose? Analysing the depth and quality of public participation in the integrated development planning process in Gauteng', Politikon 37(2-3), 223-249. https://doi.org/10.108 planning process in Gaute

Fakir, E., 2003, 'Political participation in South Africa', Paper presented at the 5th Conference of the International Network - Education for Democracy, Human Rights and Tolerance, Berlin, Foreign Ministry, May 14-15.

Freire, P., 1972, Pedagogy of the oppressed, Pelican, Harmondsworth.

Friedman, S., 2004, 'A voice for all: Democracy and public participation', Critical Dialogue: Public Participation in Review 1(1), 22-26.

Gaventa, J. \& Valderrama, C., 1999, Participation, citizenship and local governance, Background note prepared for workshop on strengthening participation in local governance, Participatory Methods, viewed 30 April 2021, from http://www. participatorymethods.org/sites/participatorymethods.org/files/ participation $\% 20$ citzienship $\% 20$ and $\% 20$ local\%20governance_gaventa.pdf.

Gonzalez de Asis, M. \& Acuña-Alfaro, J., 2002, Civic participation in local governance, viewed 18 April 2021, from http://web.worldbank.org/archive/website00818/ web/pdf/civic_-3.pdf.

Gueli, R., Van Huyssteen, E. \& Liebenberg, S., 2007, 'Integrated development planning in South Africa: Lessons for international peacebuilding', African Journal on Conflict Resolution 7(1), 89-112, viewed 21 April 2021, from https://www.accord. org.za/ajcr-issues/integrated-development-planning-in-south-africa/.

Harrison, P., 2001, 'The genealogy of South Africa's integrated development plan', Third World Planning Review 23(2), 175-193. https://doi.org/10.3828/ twpr.23.2.q4172h26466148n3

Hlongwane, N.T., 2011, 'Evaluating the integrated development plan as a performance management system for a selected KwaZulu-Natal municipality', Master of Business Administration dissertation, Durban University of Technology.

Hofisi, C., 2014, 'Making participation real in integrated development planning in South Africa', Journal for Public Administration 49(4), 1126-1138.

IDASA (Institute for Democracy in South Africa), 2011, 'Are ward committees the voice of communities?', Chapter 5 in Recognising community voice and dissatisfaction, IDASA, viewed 09 March 2021, from http:/www.idasa.org.za.

Maake, T.M., 2016, 'An analysis on integrated development planning: A case study of Mopane District Municipality', PhD thesis (Public Administration), University of Pretoria.

Madumo, O.S., 2015, 'Developmental local government challenges and progress in South Africa', Administratio Publica 23(2), 153-166.

Mogale, T., 2005, 'Local governance and poverty reduction in South Africa', Progress in DevelopmentStudies 5(2),135-143. https://doi.org/10.1191/1464993405ps106pr

Motingoe, R.S., 2011, 'The performance management system as implementation too for integrated development plans: The case of Ngwathe Local Municipality', Master of Public Management and Governance dissertation, Potchefstroom Campus of the North-West University.

Musitha, M.E., 2012, 'The role of traditional authority in integrated development planning policy implementation with reference to Limpopo Province', PhD thesis, University of Pretoria.

Ntlabezo, E.M., 2013, 'Integration of the integrated development plan and performance management processes considered', Master's in Business Administration mini-dissertation, Potchefstroom Campus of the North-West University.

Petzer, E., Oranje, M. \& Van Huyssteen, E., 2000, A policy paper on Integrated Development Planning, viewed 21 April 2021, from https://www.researchgate. net/publication/330872906

Pratchett, L. \& Wilson, D., 1996, Local democracy and local government. Government beyond the centre, Palgrave, London.

RSA (Republic of South Africa), 1993, Local Government Transition Act, 209 of 1993 Government Printers, Pretoria. 
RSA (Republic of South Africa), 1995, Development Facilitation Act, 67 of 1995, Government Printers, Pretoria.

RSA (Republic of South Africa), 1996, Constitution of the Republic of South Africa, 1996, Government Printers, Pretoria.

RSA (Republic of South Africa), 1998a, Local government: Municipal Structures Act, 117 of 1998, Government Printers, Pretoria.

RSA (Republic of South Africa), 1998b, White paper on local government, 1998 , Government Printers, Pretoria.

RSA (Republic of South Africa), 2000, Local government: Municipal Systems Act, 32 of 2000. Pretoria: Government Printers, Pretoria.

RSA (Republic of South Africa), 2001, Local government: Municipal planning and performance Regulations No. 796, 24 August 2001, Government Printers, Pretoria.

RSA (Republic of South Africa), 2012, National development plan: Vision 2030, NPC, Pretoria, viewed 21 April 2021, from https://www.gov.za/issues/nationaldevelopment-plan-2030.

RSA (Republic of South Africa), 2013, Spatial Planning and Land Use Management Act, 16 of 2013, Government Printers, Pretoria.

RSA (Republic of South Africa), 2018, Integrated planning framework bill, Government Printers, Pretoria.
SALGA (South African Local Government Association), 2011, Guideline document on the roles and responsibility of councillors, political structures and officials, SALGA,
Pretoria, viewed 10 April 2021, from https://www.salga.org.za/Documents/ Pretoria, viewed 10 April 2021, from https://www.salga.org.za/Documents/ The-Roles-and-Responsibilities-of-Councillors-and-Officials-(2)-(1st-Draft)_.pdf.

Sebei, T.M., 2013, Integrated development planning as a public model and public participation tool in Fetakgomo Local Municipality, South Africa (2000-2009), Master's in Public Administration dissertation, University of Pretoria.

Sisk, T. \& Ballington, J., 2001, International institute for democracy and electoral assistance. Democracy at the local level: The international IDEA handbook on participation, representation, conflict management, and governance, Handbook Series, p. 4, International Institute for Democracy and Electoral Assistance, Stockholm.

Thebe, T.P., 2016, 'Participation: Reality and rhetoric in the development and implementation of the Integrated Development Plan (IDP) within municipalities of South Africa', Journal of Public Administration 51(4), 712-723. https://doi.org/10 .1080/00343404.2015.1120282

Van der Waldt, G. (ed.), 2007, Municipal management: Serving the people, Juta, Cape Town.

Van der Waldt, G., 2010, 'Core theories for the teaching of local democracy', Administratio Publica 18(1), 12-29. 